\title{
The Relevance of Muhammad Abduh's Thought in Indonesian Tafsir; Analysis of Tafsir Al-Azhar
}

Zulfikri Zulkarnaini

Bursa Uludag University, Bursa, Turkey

Email: 711423018@ogr.uludag.edu.tr

Mohammed A.F. Badawi

Bursa Uludag University, Bursa, Turkey

Article History:

\begin{tabular}{|l|l|}
\hline Received: May 21, 2021 & Accepted: November 19, 2021 \\
\hline Revised: October 04, 2021 & \\
\hline
\end{tabular}

\section{Abstract}

In this study, the author uses the descriptive-historical approach to explain the influence of Muhammad Abduh's thoughts and Tafsir Al-Manar's coming to Indonesia. Especially in the Tafsir Al-Azhar by Hamka, who was born in the 20th century. This interpretation emerged when Indonesia was experiencing a state of transition from colonialism to independence. At the same time, modern Islamic thought became strong in Indonesia. The modern approach of Tafsir al-Manar has inspired Hamka's model of interpretation in Tafsir Al-Azhar. Here the authors find similarities in terms of methodology, namely social-community (Adab ijtima'i). Apart from that, there are some similarities and differences between the Tafsir Al-Manar with Tafsir Al-Azhar. For example, the view of the verses of "Ahl Kitab, muhkam-mutasyabih, and Israiliyat." Then the implications for the understanding of the heterogeneous Indonesian Islamic community from various religions. Besides this, the interpretation had a significant influence on the development of modern interpretation in Indonesia. It is easy to read and understand the general public to academics in Indonesia, Malaysia, and other Southeast Asian countries. 
Keywords; Hamka, Tafsir, Methodology, Al-Manar, Contemporary Abstrak

\begin{abstract}
Abstrack
Dalam penelitian ini, penulis menggunakan pendekatan deskriptifhistoris untuk menjelaskan pengaruh pemikiran Muhammad Abduh dan Tafsir Al-Manar ke Indonesia. Terkhusus pada Tafsir Al-Azhar karya Hamka yang lahir pada kisaran abad ke-20. Tafsir ini muncul ketika Indonesia sedang mengalami transisi dari kolonialisme menuju kemerdekaan. Pada saat yang sama, pemikiran Islam modern menjadi kuat di Indonesia. Pendekatan modern Tafsir alManar telah menginspirasi model tafsir Hamka dalam Tafsir AlAzhar. Disini penulis menemukan persamaan dari segi metodologi yaitu sosial-kemasyarakatan (Adab ijtima'i). Selain itu, ada beberapa persamaan dan perbedaan antara Tafsir Al-Manar dengan Tafsir AlAzhar. Misalnya pandangan ayat-ayat "Ahli Kitab, muhkammutasyabih, dan Israiliyat". Kemudian implikasinya bagi pemahaman masyarakat Islam Indonesia yang heterogen dari berbagai agama. Selain itu tafsir memiliki pengaruh yang signifikan terhadap perkembangan tafsir modern di Indonesia. Artinya mudah dibaca dan dipahami masyarakat umum oleh kalangan akademisi di Indonesia, Malaysia, dan negara-negara Asia Tenggara lainnya.
\end{abstract}

Kata Kunci: Hamka, Tafsir, Metodologi, Al-Manar, Kontemporer 


\section{INTRODUCTION}

The study of the Qur'an has never stopped since it was revealed until now. Al-Qur'an proves that it is the holy word of Allah. ${ }^{1}$ Therefore, the Qur'an is the core source of Islamic teachings and is also an inspiration for Muslims in their lives. ${ }^{2}$ To understand the sacredness of the verses of the Qur'an, everyone has diverse knowledge and insights. This is evident from the fact that the Qur'an has been studied by various methods and taught in various ways. ${ }^{3}$ The attention of Muslim scholars in the field of al-Qur'an Tafsir is directed by making interpretations which the times. ${ }^{4}$ The process of Muslim comprehension of the Qur'an and becoming a product of understanding which of course cannot be separated from friction each meeting of space and time when someone reading, understanding, and actualizing the verses of the Qur'an in one's social life at the intellectual level of the community. Then, in the end, it displays various forms of interpretation that are various and colorful. This is in line with the history of interpretive studies in Indonesia before and after independence. Following its sociohistorical conditions, Indonesia also has its development about the process of understanding and interpreting the al-Qur'an, which is different from the other Muslim-populated countries. However, some interpretations in Indonesia have similarities and are affected by the style of Middle Eastern interpretation. In this paper, one of them is Tafsir Al-Azhar by Abdul Malik Karim Amrullah (Hamka).

\footnotetext{
1 al-Waqi'ah (56): 77-79

2 Abdullah Saeed, Ed., Approaches to the Qur'an in Contemporary Indonesa (London: Oxford Univeristy Press, 2005), 1.

3 Ayatullah Sayyid Kamal Faghih Imani, Nur al-Qur'an: An Enlightening Commentary Into The Ligh Of The Holy Qur'an (Iran: Imam Ali Public Library, 1998), 16.

4 Abdullah Saeed, The Qur'an: An Introduction (New York: Routledge, 2008), 209.
} 
The Islamic reform movement, especially the interpretation (Tafsir) that occurred in Egypt, significantly influenced Muslims worldwide and Indonesia. In tafsir's field, the renewal was started by Muhammad Abduh and Rashid Rida in the Tafsir al-Manar. The movement for the renewal of Islamic thought demands interpreting the Qur'an contextually according to social changes. ${ }^{5}$ It means that modern Islamic society can easily understand and apply an understanding of the al-Qur'an or a more functional interpretation. Muhammad Abduh-Rashid Rida prioritized this vision and mission, namely al-Qur'an, as the guidebook in the world and the hereafter. ${ }^{6}$ After being traced, the idea of modernism brought by Muhamad Abduh and including Rashid Rida, if traced, has conformity either modernism or contemporary ideas; this is characteristic of the modern Islamic movement. This initial reform movement was championed by Sheikh Ahmad Sirhindi 1563-1624 AD, Muhammad ibn Abd Wahhab 1703-1792 AD, and Shah Waliullah Dehlawi 17031762 it is further drawn, it can reach the figure of Ibn Taymiyyah 1263-1328 AD. ${ }^{7}$ Under what Goldziher revealed, he stated that alGhazali, Ibn Taymiyyah, and Ibn al-Qayyim for Muhammad Abduh - Rashid Rida influenced his thinking. ${ }^{8}$ At least Al-Ghazali inspired them, as did Rashid Rida. He was deeply influenced by the book Ihya 'Ulum ad-Din by Al-Ghazali. Kitab Ihya Ulum ad-Din shaped his mindset and outlook. Muslims must consciously live their faith, be at

${ }^{5}$ Farid Esack, Qur'an Pluralism and Liberation (Oxford: One World, 1997), 50.

6 Abdülkadir Muhammaed Salih, At-Tafsîr Wa Mufessirûn fíl-'Asri'l-Hadîs (Beirut: Der Marife, 2003), 306. Az-Zahabi, At-Tefsîr Wa Mufassirûn, II, (Cairo: Mektebe Wahbah, nd.), 401. Rashid Rida, Tafsir al-Kur'an al-Hakim, I (Cairo: Dar El-Menar, 1947), 31.

7 Abuddin Nata, Metodologi Studi Islam (Jakarta: Raja Grafindo, 2000), 340.

${ }^{8}$ Ignaz Goldziher, Mazahib al-Tafsir, trans. Abdul Halim (Cairo: Maktabah elHanaci, 1995), 367. 
the stage of obedience, and always be aware of their actions of moral effects. $^{9}$

The reforms carried out by Jamal al-Din al-Afghani, Muhammad Abduh, and Rashid Rida flourished and were successful. The Islamic movement developed in the Middle East (1920 century) spread Islam with the approaches and principles taught by Muhammad Abduh; as time went on, they arrived in Indonesia. At that time, the spirit of new nationalism was growing (new independence). The influence of renewal was received directly (studied in Mecca and Egypt) and indirectly (through the interpretation of al-Manar and other renewal books). Therefore, the first at this research is that the writer tries to explain the historical interpretation, methodology, and the author of Tafsir Al-Azhar. Second, tracing historically how this idea of Islamic renewal came to Indonesia influenced Al-Azhar's interpretation. Third, the implications for the development of interpretation in Indonesia.

\section{RESEARCH METHODS}

This research is library research. The sources of this research are primary sources from books related to the theme of this research in the form of Tafsir al-Azhar and Tafsir al-Manar. Then also added with secondary sources, namely in books, encyclopedias, journals, magazines, etc. This research uses descriptive-history methods, which lead to exploration, extracting, and deepening of data from various sources to trace the genealogy of influence, compare the linearity of thought ideas, and finally analyze them. So that is expected to provide a complete picture of Abduh and Hamka's position in the development of interpretation studies.

9 Ibrahim Ahmad al-'Adawi, Rashid Rida al-Imam al-Mujahid (Cairo: Muassasa Misriya Amma, nd.), 36. 


\section{RESULTS AND DISCUSSION}

\section{Biography of Hamka}

\section{Hamka's Family}

Haji Abdul Karim Amrullah was widely known as "Hamka" and was born on February 19 in 1908 in Maninjau, West Sumatra. He was born to a couple of husband and wife, Shafiyah binti Bagindo Nan Batuah and Dr. Syekh Abdulkarim Amrullah. His father was a part of a Muslim reformer known as the "young faction (kaum muda)", which made an effort to free Minangkabau from Dutch colonialism and the old-fashion thoughts of the tradition of Minangkabau; the movement started in 1906 after he came back from Makkah. ${ }^{10}$ His father was also a descendant of Abdul Arif (Tuanku Pauh Pariaman Nan Tuo). He was a hero of the Padri War and a follower of "Tarikah Naqshabandy". Thus, Hamka came from an honorable and religious family.

Hamka, in his life, did not enjoy and reveal his adolescence because of the early-age marriage when he was 22 with Siti Raham binti Endah Sutan, aged 15. The marriage took place on April 29, 1929. ${ }^{11}$ However, his wife passed away on January 1, 1972 aged 58. Hamka was blessed with 10 children, 2 more children that passed away, and 2 miscarriages from that marriage. His children that lived were Zaki, Rusydi, Fakhri, Azizah, Irfan, Aliyah, Fathiyah, Hilmi, Afif, and Syakib. ${ }^{12}$ Then Hamka remarried a woman from Cirebon, West Java, almost the same age as the late Siti Raham, named Hajjah

${ }^{10}$ Solihin Salam, Kenang-kenangan 70 Tahun Buya Hamka (Jakarta: Yayasan Nurul Islam, 1978), 283.

${ }^{11}$ Hamka, Tafsir al-Azhar, I (Jakarta: Gema Insani, 2015), xii.

${ }^{12}$ Hamka Rusydi, Pribadi dan Martabat (Jakarta: Pustaka Panji Mas, 1981), 19. 
Siti Khadijah. ${ }^{13}$ This marriage was not destined to be long because Hamka passed away on July 24, 1981.

\section{Education and Social Activities}

Hamka's education started at home with his parents. Then in 1914 when he was 6 or 7 years old, he was schooled in Padang Panjang, and when he was 8 years in 1916, he was sent to Diniyyah Padang Panjang, a school that Zainuddin Labay El-Yunusi founded. Hamka often spent his time in a library belonging to Zainuddin Labay El-Yunusi_ and Bagindo Sinaro, an education expert at those times in Minangkabau. While he was busy reading a silat book, his father came and said: "Speeches alone are useless, fill them first with knowledge, then they will be meaningful and beneficial". ${ }^{14}$ After that, Hamka was sent to Sumatera Thawalib Padang Panjang, which his own father founded.

The poor condition of Hamka's family, which originated from the divorce of his parents, made Hamka unable to concentrate on his study, which made him read a lot and self-taught. In 1924, he once more visited Java. His visit to Java gave him a chance to learn more about the world of Islam. He met with Ki Bagus Hadikusumo, and from him, Hamka got knowledge about tafsir al-Quran, which was "Tafsir Baidawi". He also met with H.O.S Cokroaminoto and attended his lecture about "Islam and Socialism". He also met with other important figures such as H. Fachruddin and Syamsul Ridjal, who were members of Jong Islamieten Bond (JIB), and shared some of his thoughts. From here, finally, he was exposed and knew how to compare the Islamic movement, "Islamic Union (Syarikat Islam)", East Indies, and the social movement of Muhammadiyah. Then he

\footnotetext{
${ }^{13}$ Rusydi, Dan Martabat, 34.

14 Yunan Yusuf, Corak Pemikiran Kalam Tafsir Al-Azhar: Sebuah Telaah Atas Pemikiran Hamka dalam Teologi Islam (Jakarta: Penerbit Penamadai, 2003), 41-42.
} 
went to Pekalongan to meet his in-law Sutan Mansur and also to study religion from him. ${ }^{15}$

In 1925 when he was 17 years old, Hamka went back to his village. He founded speech courses for the young at his father's surau, and even those speeches were made into a book titled "Khatibul Ummah". ${ }^{16}$ When he was busy doing all of those activities, he also got challenges from people who despised him, even from his father that said that it was "useless" for one to just make a speech without enough knowledge, ${ }^{17}$ thus he felt motivated and left his village in search of knowledge and experiences. In 1927 when he was 19 years old, he visited Makkah to perform hajj without his father's knowledge. When in Makkah, he read important books and attended lectures from sheikhs there. He stayed in Makkah for 6 months, and when he came back, he didn't go to his father, rather he went and settled down in Medan.

On December 18, 1949, Hamka went to Jakarta to start his career. In Jakarta, he worked at the Department of Religious Affairs. He taught in some Universities as a lecturer, and finally, he was inaugurated as a rector in "Perguruan Tinggi Islam Jakarta" and as a professor in Universitas Moestopo Jakarta. ${ }^{18}$ He was also installed as a civil servant from 1951-1960. Another occupation of Hamka was to write in various newspapers and magazines. Hamka was also often invited to give sermons and lectures explaining Islam in various countries such as the USA, Iraq, Pakistan, Saudi Arabia, Egypt, Malaysia, etc. From the University of Al-Azhar, he was given the honor of Doctor Honoris Causa in 1958. From the National University of Malaysia in 1974, he gave a lecture about Malay and its relation

\footnotetext{
${ }^{15}$ Rusydi, Dan Martabat, 2.

${ }^{16}$ Hamka, Kenang-Kenangan Hidup (Jakarta: Bulan Bintang, 1974), 105.

${ }^{17}$ Hamka, Kenangan Hidup, 106-107.

${ }^{18}$ Badiatul Razikin, 101 Jejak Tokoh Islam (Yogyakarta: e-Nusantara, 2009), 191.
} 
with Islam. ${ }^{19}$ At the final stage of his life, Hamka becomes the grand imam of Al-Azhar mosque in Kebayoran Baru, Jakarta, where he delivered tafsir al-Quran. Hamka passed away on July 24, 1981, and produced works in various fields such as religion, philosophy, and literature.

\section{History of Tafsir Al-Azhar and Methodology \\ History of Tafsir Al-Azhar}

This tafsir is written to provide a good understanding to the Indonesian Islamic communities whose are different from cultures and religions. The "Al-Azhar" name is taken from the mosque's name where the tafsir lectures were delivered by Hamka himself, namely the Al-Azhar mosque, Kebayoran Baru. Al-Azhar mosque itself is a gift from Sheikh Mahmoud Shaltut, the chancellor (Grand Sheikh) of Al-Azhar University who came to Indonesia in December 1960. With this name, Sheikh Mahmoud Shaltut hopes that in Indonesia, there will be Al-Azhar like Al-Azhar in Cairo-Egypt. The name Tafsir al-Azhar expresses Hamka's gratitude to Al-Azhar University for awarding him the Honoris Causa Doctor. This tafsir was originally a recitation of the dawn interpretation carried out routinely by Hamka at the Great Mosque of Al-Azhar since 1959. ${ }^{20}$ This activity was carried out to convey Islamic teachings to the Indonesian people, especially the people around his residence. Hamka's interpretation started from Surah al-Mukminun / al-Kahfi, Juz XV. Because Hamka thought it was possible that he did not have the chance to accomplish a complete commentary on this tafsir during his lifetime. Until January 1964, he had not yet managed to complete the entire Qur'an. Likewise, Hamka has tried to write

\footnotetext{
${ }^{19}$ Razikin, Tokoh Islam, 190.

${ }^{20}$ Yusuf, Teologi Islam, 3.
} 
successively in Gema Islam magazine from January 1962 to January 1964, but only 1 and a half juz from chapters 18 and 19 can be published. ${ }^{21}$

At that time, Indonesia's political conditions were not right, and Hamka was slandered until he went to jail for three years (19541966). While in prison, he continued to write Tafsir Al-Azhar. ${ }^{22}$ Hamka specifically wrote this tafsir in the Indonesian (Melayu) language. Because Indonesian language experts formulated the Indonesian state language problem at the "Indonesian Language Congress" in 1954, it resulted in an agreement between linguists and Indonesians that the Indonesian language originates and is based on the Malay language. ${ }^{23}$ Historically, Malay is the language commonly used by Indonesians, even in Malaysia, Singapore, Brunei Darussalam, and the southern part of Thailand since the 7th century.

Hamka begins his tafsir with an introduction (muqaddimah) that is quite long, 47 pages thick with 9 chapters of discussion. In the introduction to this book, Hamka mentions people who are very influential in shaping his personality, namely by paying respect to 4 important people, Haji Abdul Karim, Ahmad Rashid, Sutan Mansur, Siti Raham, and Safiah. In the Introductory Chapter, Hamka explains the importance of interpreting the Qur'an in Malay on the condition that it meets the basic requirements of interpretation as determined by the scholars. In the next Chapter, Hamka extensively discusses various issues related to the Qur'an and tafsir, namely in the Chapter "Al-Quran", Chapter "I'jaz Al-Quran", Chapter "Contents of AlQuran Miracles", Chapter "Al-Quran Lafaz and Meanings" and Chapter "Interpreting Al-Quran". The most important chapter is the

\footnotetext{
${ }^{21}$ Hamka, Tafsir Al-Azhar, I, 47.

${ }^{22}$ Hamka, Tafsir Al-Azhar, I, 50.

${ }^{23}$ Hamka, Tafsir Al-Azhar, 1, 3.
} 
"Direction of Tafsir", because, in this chapter, Hamka explains the method of writing al-Azhar's tafsir.

Hamka's aim in writing this commentary consisted of 4 factors;

1. Translating and interpreting the al-Qur'an verses into Indonesian or Malay is a continuation of previous ancestors' efforts, such as Sheikh Abdurrauf ibn Ali Fansuri in 17 th century Aceh.

2. Hamka's desire to give enthusiasm and faith to the younger generation of Indonesian Muslims, especially those who have deficiencies in Arabic but want to understand and learn the al-Qur'an. It also makes it easier for Indonesian Muslims from various circles who want to study religion and know the al-Qur'an's miracles.

3. Facilitate the to an understanding of preachers and preachers.

4. Hamka wants to leave a legacy that is beneficial to the Indonesian nation and Muslims.

The first publication of Tafsir Al-Azhar was carried out by the Pembimbing Masa Publisher in 1966, led by Haji Mahmud. The first printing by the Pembimbing Masa completed the publication of juz 1 to juz 4 in 1968. Then juz 30 and juz 15 to juz 29 were also published by Pustaka Islam Surabaya in 1973. Moreover, finally, juz 5 to juz 14 were published by Nurul Islam Foundation Jakarta in $1975^{24}$ and finished publishing in its entirety 30 juz at the first time when he was 73 years old. Finally, the Tafsir al-Azhar was collected to be more compact into nine volumes; Gema Insani published 30 juz large, this interpretation of Al-Azhar in August 2015 in Jakarta. While the writing itself took about 16 years (starting from 1962-1978). Even though his commentary had been published, Hamka still made corrections and revisions until 1979.

\footnotetext{
${ }^{24}$ Hamka, Tafsir Al-Azhar, 45-46
} 


\section{Tafsir Al-Azhar Methodology}

The development of the tafsir of the Qur'an from the past until now can be broadly categorized into four methods, namely ijmali (global), tahlili (analysis), muqarin (comparison), and maudu'i (thematic). Hamka in the Howard M. Federspiel categorization includes the third generation of commentaries, namely the commentary book that is present to comprehend the contents of the Qur'an comprehensively. Therefore it contains material about text and methodology in analyzing tafsir. In terms of method, Tafsir alAzhar can be categorized as tafsir tahlili, ${ }^{25}$ namely the tafsir that explains the verses of the Qur'an by examining their aspects in detail and detailed and revealing all their meanings starting from the description of the meaning of the vocabulary, the meaning of the sentence, the meaning of each expression, the relation between the dividers (munasabah) to the side of the interconnection between the separators (wajh al-munasabah) with the help of asbab al-nuzul, narrations from the Prophet, the companions (shahabah) and companions of the companions (tabi'in). The procedure for the tahlili method is carried out by following the arrangement of the mushaf, ayat (verse) by ayat (verses), and chapter (surah) by chapter (surah) from beginning till the end.

The main characteristics of Tafsir Al-Azhar by using the tahlili method include:

a. Discusses everything related to the verse from all sides.

b. Explaining the asbab al-nuzul of the interpreted verse.

25 Milhan Yusuf, "Hamka's Method Of Interpretıng The Legal Ayats Of The Qur'an: A Study Of His Tafsıral-Azhar" (Master Thesis, Canada: McGill University, 1995), 20. Howard M Federspiel Deepening Faith and Strengthening Behaviour: Indonesian Studies of Qur'an and Hadith, (Jakarta: Privately Published, 1987), 99. 
c. Interpreting verses sequentially and discussing the relationship between verses and other verses to explain the interpretation.

d. Tafsir tahlili or, in other words, tafsir bi al-ma'thur, when the focus is on the hadith, sahabah opinion, or the opinions of muslim scholars, which are then confirmed by the ratio (al$\left.r a^{\prime} y i\right)$. Conversely, it can also take the form of tafsir bi alra'yi if the pressure point of interpretation is based on ratio. At the same time, history is positioned only as a logic of interpretation.

In writing his commentary, Hamka took the following steps:

1. Write the verse and its translation.

2. Explaining the meaning of the surah, sometimes explaining the place and time of the verse.

3. Explaining asbabun-nuzul.

4. Mention the interpretation of the al-Qur'an, hadith, and the opinion of sahabah and tabi'in.

5. Explain the history (sirah) of the Prophet, sahabah.

6. Explaining the different views of the commentators.

7. Correlate the content of the verse with the context of the commentator.

8. Explaining the personal life story of the commentator or other people if it has something to do with interpretation.

9. Mention ancient prose or poetry.

10. Ending the interpretation with conclusions, lessons, and invitations to think about it.

Tafsir Al-Azhar has a style of interpretation of Al-Adab AlIjtima'i (social society). This style emphasizes the explanation of the ayats of the Qur'an in terms of their editorial accuracy, then arranges their contents in a beautiful editorial by highlighting the aspects of the al-Quran's instructions for life and connecting the meaning of 
these ayats with natural laws that apply in society and the development of the world without using of disciplinary terms except within the limits that are really needed.

According to Abd al-Hayy Al-Farmawi, the style of Al Adab Wa Al-Ijtima' $i$ is one method of analysis of the culture and social problems which focuses on the explanation of al-Qur'an ayats in terms of their editorial accuracy, then arranges their contents in a beautiful editorial with highlight the aspects of the Qur'anic guidance for life. ${ }^{26}$ In agreement with this, Az-Zahabi said that this interpretation seeks to analyze and criticize the Qur'anic texts by showing their editorial accuracy, and packaging them into beautiful language, then synergizing the ayats of the Qur'an with community problems that flourished at that time. ${ }^{27}$ However, in this modern era, a new paradigm has emerged among the commentators. They pay more attention to the beauty of the composition of the Qur'an (balaghah) and the social conditions as well as the thoughts and schools of thought that developed at that time. ${ }^{28}$

From the above definitions, it can be concluded that Tafsir alAzhar which Al-Adabi Al-Ijtima'i characterizes is a method of interpretation which emphasizes:

a. The majesty and precious of the composition of the language of the al-Qur'an.

b. Analyzing social problems and providing religious solutions.

c. This interpretation emphasizes the preciousness of the style of the Al-Quran language and the accuracy of its editorial.

26 Abd al-Hayy Al-Farmawi, Al-Bidayah fi Al-Tafsir Al-Maudhu'i (Cairo: AlHadarah Al-'Arabiyah, nd), 23-24.

${ }^{27}$ Muhammad Husein Az-Zahabi, Al-Tafsir wa Al-Mufassirun (Cairo: Maktabah Wahbah, 2005), 424-425.

28 Manna' al-Qathan, Mabahis fi 'Ulum Al-Qur'an (Cairo: Maktabah Wahbah, 2000), 360-361. 
It contains wisdom that can provide a touch of faith and intellectual stimulation.

d. The meaning covered by the verses of the al-Qur'an is related to the universal order (sunnatullah) and the function of reason in explaining the al-Qur'an verses.

e. This interpretation explains the law of Allah that applied to the previous ummah to encourage more "down to earth of the al-Qur'an" in society based on moral values derived from the Qur'an.

f. This interpretation model also uses riwayah (atsar) and history so that it can be said that this interpretation combines the approaches of reason, atsar, and history.

Thus, it can also be said that the Tafsir al-Azhar uses the Salafi style of interpretation. In the sense that the writer adheres to the mazhab of the Prophet and his companions and scholars who follow in his footsteps. This is as Hamka admits in the course of his interpretation (Tafsir): "The school followed by this Interpreter (mazahib tafsir) is the Salaf school, namely the school of the Prophet and his companions and the scholars who followed in his footsteps. In terms of faith and worship, solely taslim, means giving up without asking too many questions. But it is not merely an imitation of human opinion, but rather observes which one is closer to the truth to be followed and leaves what is far distorted. Although the distortion that far is not due to some bad intention from the issuer of that opinion". ${ }^{29}$ A concrete example to show the Salafi of Tafsir al-Azhar is when discussing the opening of a chapter (fawatih al-suwar). In this case, the interpreter of the Tafsir Al-Azhar chooses to leave his understanding solely to Allah because it is judged to be safer and also not in direct contact to deepen and study the Qur'an.

${ }^{29}$ Haluan Tafsir in Mukaddimah in Tafsir Al-Azhar, 38. 


\section{Influence and Tafsir Al-Azhar References}

In terms of choosing a source of reference for Tafsir Al-Azhar, Hamka is not fanatical about one interpretation work and is not fixated on a single school of thought. Hamka quoted from various commentaries, books of hadith, philosophy, history, etc. However, several commentary books greatly influence their interpretation, both in terms of their thoughts and styles. Among them is Tafsir AlManar, Hamka stated in his Tafsir that he admired Muhammad Abduh and Rashid Rida's model and interpretation of al-Manar, meaning that Tafsir al-Manar heavily influenced Hamka's interpretation. In the introduction to Tafsir Al-Azhar, Hamka wrote the following, "The interpretation which is very attractive to the interpreter to be used as an example is the Tafsir Al-Manar by Rashid Rida, based on the teachings of his teacher Sheikh Muhammad Abduh. His interpretation, apart from describing science with respect to religion, regarding hadith, figh and history and others, also adapts these ayats to the political and social developments that occur in accordance with the era at which the interpretation was written", ${ }^{30}$ especially in terms of linking interpretation by paying attention to history and contemporary events. $^{31}$

In his tafsir, Hamka mentioned that while studying in Sumatra Thawalib Padang Panjang in 1922, Muhammad Abduh's "Tafsir al- 'Asr", which was published regularly by Muhammad Rashid Rida, was one of the books taught at the educational institution. That interpretation and Muhammad Abduh's translation of Tafsir Juz 'Amma into Indonesian language is also used in this madrasah. The use of Muhammad Abduh's works began in 1924 and continues until today.

\footnotetext{
${ }^{30}$ Hamka, Mukaddimah Tafsir Al-Azhar, I, 38.

${ }^{31}$ Howard M Federsipel, Kajian-Kajian Al-Qur'an di Indonesia (Bandung: Mizan, 1996), 142.
} 
In addition to being oriented towards the Tafsir al-Manar, Hamka, in writing his interpretation, also followed the flow of the tafsir Fi Zilal al-Quran by Sayyid Qutb's. This can be seen by the approach used by Hamka, which is a literary approach, namely the explanation and understanding of ayats or lafadz using literary expressions. One of them is the domination of munasabah (correlation) between the passages of the ayats. The use of munasabah marks the similarity of the Tafsir al-Azhar to the Tafsir Fi Zilal alQuran, which also proves the truth of Hamka's admission that the interpretation that influences him is the interpretation of Tafsir Fi Zilal al-Quran and Tafsir al-Manar. Apart from that, also from the Tafsir al-Qasimi and Tafsir al-Maraghi. These 4 interpretations influenced Hamka the most in his interpretations. However, other classical interpretations, Orientalist books, and the Old Testament have also become Hamka's references in interpreting the Qur'an. This is proven by the end of Hamka's volume presenting all the references he took in the process of interpreting the Qur'an. What Hamka did became a special characteristic of the more scientific tafsir in Indonesia between the existing and previous interpretations.

\section{The Relationship Between the Tafsir al-Azhar and Tafsir al-Manar The History of The Influences of Abduh's Thought on Indonesia}

Hamka said the spread of Islam was brought by the Arab community who migrated to trade and settled in Indonesia since the early 19th century. They are regular subscribers of the magazine al'Urwat al-Wutsqa (published in France in 1884), which contains ideas for the renewal of Jamal al-Din al-Afghani updates in interpretations by Muhammad Abduh. After the Dutch colonialists banned the magazine from circulating in Indonesia, these loyal customers could still obtain it by smuggling through a small port in the Tuban area, 
East Java, even as the name changed from "Urwatul Wusqa" to "alManar" magazine, which contained a commentary by Muhammad Abduh. ${ }^{32}$

Hamka mentions that Muhammad 'Abduh in Indonesia (Nusantara) was pioneered by Sheikh Tahir Jalaluddin, a loyal customer magazine al-Manar, from the beginning to the end of the publication. He continued his education at al-Azhar University in Egypt around the year 1310/1892. While in Egypt, he was much influenced by Muhammad Abduh because he was friendly with Rashid Rida, and it is thought that he studied with Muhammad Abduh himself. ${ }^{33}$

Another well-known figure in Indonesia (Nusantara) from Kelantan (Malaysia) was named Tok Kenali. He contributed to the development of recitation and commentary (tafsir) writing. Jamal alDin al-Afghani and Muhammad Abduh's influence was enormous in their religious thinking. In his Tafsir, Hamka mentioned that while studying in Sumatra Thawalib Padang Panjang in 1922, the "Tafsir of surah al-'Asr" and the "Tafsir Juz' Amma" by Muhammad Abduh was the books he studied. Even the interpretation of Juz' Amma was translated into Indonesian at that time. The use of Muhammad Abduh's books began in 1924 and continues today.

Finally, the influence of Muhammad Abduh and Rashid Rida in Indonesia was brought by Indonesian scholars who studied in the Middle East (Egypt and Mecca) in the 19th century. Furthermore,

32 Fadzilah Din, "The Contribution of Tafsir Al-Manar and Tafsir Al-Azhar Toward Understanding The Concept of Ta'ah And Its Observance: A Theological Enquiry", (Doctoral Thesis, University of Edinburgh, 2001), 11. Abdul Manan Syafi'i, Pengaruh Tafsir al-Manar terhadap Tafsir Al-Azhar, Miqor Dergisi, vol 38, 2, UIN Sumut, 2014, 266. Hamka, Pengaruh Muhammad 'Abduh di Indonesia (Jakarta: Tintamas, 1961), 30-31.

${ }^{33}$ Kevin W. Fog, "Hamka's Doctoral Adress, at Al-Azhar; The Influence of Muhammad Abduh in Indonesia", Indonesian Interdisciplinary Journal of Islamic Studies, 11, 2, (2015): 132. 
this has inspired ideas for reform in Indonesia through schools, Islamic organizations in Indonesia, and many Islamic Movement magazines such as al-Munir. The magazine was led by Haji Abdullah Ahmad, Haji Muhammad Thayeb, and Dr. Haji Abdul Karim Amrullah (Haji Rasul) in 1911 in Padang Panjang, West Sumatra (Indonesia).

\section{Similarities Between Tafsir al-Azhar and Tafsir al-Manar}

Among the interpretations that Hamka refers to most in his tafsir is the Tafsir al-Manar by Muhammad Abduh and Rashid Rida. Among them are;

Among the interpretations Hamka referred to most were Muhammad Abduh and Rashid Rida's Tafsir al-Manar. Among others are. As an example of interpreting the problem of "Ahl-Kitab" verses. Among the verses are Surah al-Fatihah; 7. In this verse, the writer briefly states that "the angry people with God are Christians and are deceived by Allah. Because the Jews denied all instructions given by the Apostle, and they acknowledged it. Christians go astray because they are too purifying, love Jesus, and admit Allah's son. "Then Hamka quoted Muhammad Abduh's entire opinion in alManar's interpretation. ${ }^{34}$ Then in the Surah al-Baqarah; 120, AliImran; 118, Al-Anfal; 72, Mumtahanah 8-9.

From several examples of these verses regarding the relationship between Muslims and non-Muslims, Hamka and Abduh-Rida do not differ. From the form of their interpretation, both seem loose and consider the Muslim community's conditions at that time. Muhammad Abduh-Rashid Rida saw and emphasized the relationship between Muslims and non-Muslims in Egypt, especially in Europe. Meanwhile, Hamka explained the condition of Muslimnon-Muslim relations in Indonesia. Because in Indonesia, the existing

\footnotetext{
${ }^{34}$ Hamka, Tafsir Al-Azhar, I, 79, Rida, Tafsir Kur 'âni'l-Hakîm, I, 69-71.
} 
religions were Christian, Hinduism, and Buddhism, while there were not so many Jews at that time. The conclusion is that what the author sees allows work, political, and social relations with non-Muslims, but with terms and conditions agreed upon between Muslims and non-Muslims according to the rules of Islamic law. Also, it prohibits contact in matters related to religion. Interpretation like this shows the social-social interpretation approach model (Adab ijtima'i), adjusting the verse's interpretation with the living conditions of the mufassir.

In explaining Surah Al-Fil: 4. Hamka introduced differences in opinion of the commentators regarding the "stone of torture" above, but Hamka did not seem to reveal it more broadly and deeply. Despite these differences, Hamka seems to emphasize his position in support of Muhammad Abduh's opinion, namely interpreting it as "smallpox." By citing information from Ikrimah, smallpox's existence had only existed since the expansion of Abrahah al-Asyram alHabasyi in destroying the Kaaba. ${ }^{35}$

Then another example is (Surah Ali-Imran (3): 104). After explaining the importance of Islamic da'wah in human life. Hamka explained that the modern model of preaching is far different from the past. There are several conditions for a preacher in modern times. He wrote: Sixty years ago, meaning the beginning of the 20th century. Muhammad Abduh has explained what the conditions must be in mind and the heart of a preacher. Although this condition was long ago, 60 years had passed. According to the notes written by Rashid Rida in Tafsir al-Manar, namely:

1. Have sufficient knowledge of the Qur'an, Sunnah, the history of the struggle of the Companions and previous people (salaf al-shâlihîn), and problems related to the laws.

35 Hamka, Tafsir AL-Azhar, IX, 668. Muhammad Abduh, Juz 'Amma, (Cairo: Syirkah Musahamah Misriyyah, 1341/1922), 157-158. 
2. Knowing the educational background, placement, culture, origins of the community, and the morals of the people who are the da'wah object.

3. Having knowledge of history in general.

4. Knowing geography.

5. Know psychology.

6. Mastering and possessing moral knowledge.

7. Know sociology.

8. Knowing about the political system and developments in the country where da'wah is.

9. Knowing about the language of the people being preached.

10. Knowing a little about the arts and skills that dominate the local people's lives gives a straightforward explanation of Islam.

11. Knowing about the points of teachings in various religions and schools of thought and their differences makes it easier for people to understand the preaching.

After finishing explaining these matters and also giving an example in the context of the society in Indonesia (Nusantara), Hamka wrote again: "Thus, in a nutshell, we explain 11 knowledge requirements of da'wah according to Muhammad Abduh which are essential to be prepared by a preacher. ${ }^{36}$

Then in the case of Hamka, it is the same as Muhammad Abduh in seeing "(taqlid; taking religious opinions without knowing the exact arguments)." Mumhammad Abduh also called on the interpreters to free themselves from the confines of taqlîd, to think creatively by using the potential of reason to reveal the meaning of the Qur'an. Avoid the interpretation of Isra'ilîyât stories, and give a large portion of understanding the al-Qur'an. However, regarding the verses that are "mubhâm," he tends to be silent and does not

\footnotetext{
${ }^{36}$ Hamka, Tafsir Al-Azhar, II, 28-33.
} 
discuss the meaning and nature of the verse in detail. He prefers to take the straight path and leave it as it is. ${ }^{37}$

Another example is the case of passages Israiliyat, Muhammad Abduh in Tafsir Al-Manar mentions repeatedly warned to be wary of liability stories, stories of the prophets of Bani Israel, described by the commentators in the books of tafsir. However, it is possible to use Israiliyat in explaining the verses of the Qur'an if it is under the verses and narration of the hadith. Muhammad Abduh did not criticize if the story's source came from the Torah, the Bible, and others as long as the contents do not conflict with shari'ah and reason. ${ }^{38}$

For Hamka Israiliyat are many stories from the Jews; the most famous are Ka'bul Ahbar and Wahab ibn Munabbih. ${ }^{39}$ Therefore in tafsir al-Azhar and tafsir al-Manar, many quotations from the Old and New Testaments clarify the Torah, the Gospel, and the books held by the People of the Book from the very contradictory meaning of "Israiliyat." Like the example of Hamka and Muhammad Abduh in interpreting the verse an-Nisa 1, they reject the israiliyat hadith about women created from the ribs of Adam. Thus, Muhammad Abduh and Rashid Rida have the same view of the Torah. They both take from the Torah in its interpretation and allow it when it does not contradict the Qur'an and hadith. Then tafsir al-Baqarah: 37-38. The hadiths about the descent of Adam from Heaven to Earth are partly Israiliyat. $^{40}$

In another example, regarding the verses of MuhkamMutasyabih, Hamka, and Muhammad Abduh in almost the same

${ }^{37}$ Muhammad b. Lutfî al-Sabbâgh, Lamahât fî̀-'Ulûm Kur'ân (Beirut: Maktabah alIslâmî, 1990), 314.

${ }^{38}$ Muhammad Husein Az-Zahabi, İsrailiyat fi-Tafsir wa Hadis (Cairo: Majalat alAzhar, 1968), 191-192. Rida, Kur'âni'l-Hakîm, 10.

${ }^{39}$ Hamka, Tafsir Al-Azhar, I, 29.

${ }^{40}$ Hamka, Tafsir Al-Azhar, II, 167. Rida, Tafsir Kur 'âni'l-Hakîm, 284. 
idea. For Muhammad Abduh mutasyabihât is a verse with several meanings, and it is difficult to determine an exact meaning for the verse. According to Muhammad Abduh, these verses of muhkamât are used as a reference to other verses in interpreting the Qur'an and are verses recommended by Allah as reference material. ${ }^{41}$ Example of Surah al-Imran: 7. In understanding this verse, Muhammad Abduh tends to argue that the verses of mutasyabihat can be known by "people who are in his knowledge." This means that Muhammad Abduh agrees with the person who said that the letter

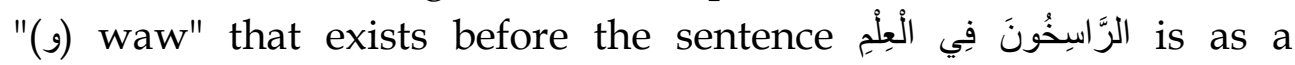
connecting letter, and not as a letter "al-isti'naf" or the beginning of a new sentence. Muhammad Abduh believed that not a single verse of the al-Qur'an was revealed by Allah, the meaning of which was unknown to the Messenger of Allah, and also those who had extensive, in-depth knowledge. Muhammad Abduh argued that many verses had to be ta'wil (interpreted), and humans could understand them.

The Qur'an is all understood (understandable). According to some scholars, if a verse is considered a problem/doubt (mutasyabihat), then the verse will be known and can be understood by other scholars. Allah cannot send down a kalam (revelation) with no meaning or send a revelation, but the Prophet and the people cannot understand its meaning. Even the Salaf scholars only handed over the interpretation ( $t a^{\prime}$ wil) of the mutasyabihat verses to Allah. Then some try to interpret it (ta' wil) versus mutasyabihat. Like Imam Mujahid ibn Jabr, al-Rabi ibn Ja'far ibn Zuber. Then about ta'wil, Abduh also elaborated on the breadth and detail of ta'wil in the Qur'an, and he chose the opinion of the school of scholars who think that those in his knowledge (الراسخون) can know ta'wil verse

\footnotetext{
${ }^{41}$ Muhammed İmârah, el-Emâl Kemile, I (Cairo: Der al-Surûk, 2009), 9.
} 
mutasyabihat. However, in this presentation, Abduh did not explain in detail and clearly how his concept of ta'wil.

\section{Differences in interpretation of Tafsir al-Azhar and Tafsir al-Manar}

In the Tafsir Al-Azhar, the writer found that Hamka was not much different from Tafsir al-Manar in interpreting the verses of the Qur'an. Although there are differences, Hamka only explains a little, which only adds to the variety of opinions of the commentators in alAzhar's interpretation. Among the things that the authors find the differences are; When interpreting the Surah al-Baqarah: 269. ${ }^{42}$ In explaining the word "Hikmah". Hamka explained that wisdom is broader than knowledge; even the results of the knowledge sought are the beginning of wisdom. Wisdom knows what is implied, real, exists rather than what is express, unseen, invisible. The wisdom expert can deeply feel God. Therefore, wisdom is also called wise, and experts of wisdom in Arabic are called "al-Hakim", which is one of Allah's names. Then Hamka explained the wisdom according to Muhammad Abduh. Wisdom is true and accountable knowledge, influencing people, determining good work, and benefiting oneself and others. Allah gives wisdom to whom He wills. Through the intellect and heart of man. The mind and heart are tools for man to decide his will (desire) from doubt. ${ }^{43}$

In another example, when interpreting the Surah of Ali-Imran: 55. Hamka interprets the word "mutawaffika" is as "killing." Killing means to die. Because in the Qur'an, the words "mutawafa" are dead / dying like "tawaffa-tawaffahumul-malaikatu," which means dead. So this verse explains that Allah killed Jesus and was raised to the side of God, and then Jesus himself was cleansed from the interference of

42 "He granteth wisdom to whom He pleaseth; and he to whom wisdom is granted receiveth indeed a benefit overflowing; but none will grasp the Message but men of understanding."

${ }^{43}$ Hamka, Tafsir Al-Azhar, I, 539. Rida, Tafsir Kur 'âni'l-Hakîm, III, 75. 
the unbelievers. However, Hamka further explained that these commentators have different interpretations. In Tafsir al-Manar, it is explained that there are two opinions. First, Allah raised the Prophet Jesus's body in a state of life and will come down again at the end of time to explain the religious law to humankind. The second is the meaning of "tawaffa" which is dead and "rafa' $a$ " raised. This means that his spirit was raised after the Prophet Jesus died. Then Rashid Rida explained that there is no apparent reason and proposition; it is evident in the Qur'an that the Prophet Jesus was taken up to heaven with his body and will later be sent down from heaven. Such an understanding is only the creed of Christians. Moreover, this tafsir al-Manar's conclusion is the problem of khilafiyah (differences) among the scholars. According to the authors, Hamka and Muhammad Abduh-Rashid Rida's interpretations are different in explaining them in detail because this is in many differences of opinion of Islamic scholars (ulama). ${ }^{44}$

Another example is when Hamka and Muhammad AbduhRashid Rida interpreted Surah Sajadah: 4 and al-Qaf: 38 about Allah creating the heavens and the earth in 6 days. Hamka interprets six days with the alternation of days that we experience, starting from Sunday-Friday. It can also be interpreted as day, night, evening, and morning for six days, six nights. Allah created all of the heavens and the earth and created what is between the heavens and the earth. Many classical commentators have interpreted this kind of interpretation. However, with the advancement of science, interpretation may change. As Muhammad Abduh-Rashid Rida interpreted, six days could be six seasons, six ages, and one era can be interpreted as years. So what is certain is that the interpretation is according to Allah's knowledge. Here lies a slight difference between Hamka and Muhammad Abduh-Rashid Rida's understanding of the

\footnotetext{
${ }^{44}$ Hamka, Tafsir Al-Azhar, I, 637-639. Rida, , Tafsir Ḳur'âni'l-Hakîm, III, 316-317.
} 
6-day verse. However, Hamka, at the end of his interpretation, did not leave or deny al-Manar's interpretation. ${ }^{45}$

Then another example is the Surah al-Zalzalah: 7-8. Hamka interprets the word "zarrah" as dust. However, he explained again, the meaning of the word "zarrah" is more subtle than dust. So with the development of technology that is finer than dust is the "atom." Arabic physicists define zarrah as "al-Jauharul-Fard," a very subtle thing that can no longer be divided. So this verse can be interpreted as "And whoever does well as much as the size of God will see it." It means that nothing can be hidden from God and will get the same reward. While Muhammad Abduh explained this verse, all good deeds, evil, big, and small, will be judged and rewarded by God. Either those who do it are infidels or Muslims. Even the deeds of infidels are rewarded by Allah and still get punishment from Allah for their disbelief. ${ }^{46}$

The last example is the Surah al-'Asr; 1. Hamka interprets 'Asar, with Asr time, in the afternoon, when the shadows are getting longer than the body until it is the time for Asar prayer. Hamka also explained another meaning of the times we pass in life, era after era, the period after era; this is also known as Asar. That's why when the Dutch colonized Indonesia, it was also known as "Asru Isti'maril Holandy" (Dutch colonial period). Allah took an oath with "Times/ Asr" to remind humans not to waste time.

Meanwhile, Muhammad Abduh-Rashid Rida explained the customs/customs of the Arab community, who, in the afternoon, have a habit of sitting around relaxing, talking about life, and others. Moreover, often talk about things that are not important, even to fighting enemies. So some curse time 'Asr. However, Muhammad Abduh explained that it was not the time 'Asar is wrong, but the

\footnotetext{
${ }^{45}$ Hamka, Tafsir Al-Azhar, VII, 120. and VIII, 465.

${ }^{46}$ Hamka, Tafsir Al-Azhar, IX, 642. Muhammad Abduh, Juz 'Amma, 141.
} 
humans who use the time are wrong; it is useless, causing adverse effects. $^{47}$

\section{DISCUSSION}

The geology, methodology, and way of interpreting Hamka in the interpretation of al-Azhar have similarities with Muhammad Abduh-Rashid Rida (Tafsir al-Manar). Moreover, suppose it is traced or traced. In that case, it will arrive at this initial renewal movement championed by Ahmad Sirhindi (d. 1624), Muhammad bin Abdul Wahhab (d. 1792), Shah Waliyullah Dahlawi (1762) to Ibn Taymiyyah (d. 1328). In general, having conformity with the ideas of renewal, modernism, and contemporary is the hallmark of the modern Islamic movement.

Therefore, in general, the relevance of Muhammad AbduhRashid Rida's thought (tafsir al-Manar) to Hamka's thought (tafsir alAzhar) is that sometimes Hamka's interpretation when quoting alManar's interpretation only quotes Muhammad Abduh's opinion, sometimes it only quotes Rashid Rida's opinion. And also often quoted the opinion of both. The total number of quotations from alFatihah to An-Nas is approximately 68 quotations in 9 volumes of Tafsir al-Manar. Then, sometimes displaying Tafsir al-Manar as it is, and sometimes summarizing it, taking the gist from Muhammad Abduh-Rashid Rida's interpretation. Hamka, in quoting only selects tafsir from Tafsir al-Manar or other interpreters (mufassir), criticizing and adding what is necessary. He explained a verse by describing the meaning of his words from Arabic to Indonesian, without including differences of opinion of scholars on the language. He did not force Muhammad Abduh-Rashid Rida or other commentators. Instead, it gives readers complete freedom to use their common sense in understanding and appreciating the content of the Qur'an after

\footnotetext{
${ }^{47}$ Hamka, Tafsir Al-Azhar, IX, 654. Muhammad Abduh, Juz 'Amma, 152.
} 
knowing its true meaning in general. He explains from Tafsir alManar to strengthen his interpretation so that Hamka's interpretation of a verse is broader and more profound. After comparing the Tafsir of al-Azhar with Tafsir al-Manar, the author's point is that sometimes it differs in the interpretation of words, but the meaning and purpose are the same.

As an example, in explaining An-Nisa: 3, which is often interpreted as a verse about the permissibility of polygamy. Muhammad Abduh considered that permitting polygamy in Islamic teachings was an act that was limited by stringent conditions. Thus, the existence of this requirement shows that the practice of polygamy is an emergency measure that can only be done by people who need it. ${ }^{48}$ In this matter, Hamka explained that this verse is closely related to the previous verse, namely paying attention to orphans, not cheating on orphans. However, psychologically and sociologically, polygamy can be an option in overcoming various psychological problems (sex appeal), the sociology of human marriage relations. However, humans have reason to choose right, not burdensome. Marriage is a matter of responsibility, livelihood, and heredity, so a

\footnotetext{
${ }^{48}$ Muhammad Abduh considered that permitting polygamy in Islamic teachings was an act that was limited by stringent conditions. Thus, the existence of this requirement shows that the practice of polygamy is an emergency measure that can only be done by people who need it, not for everyone. Not every muslim, Muhammad Abduh and Rashid Rida interpreted it with an emphasis on the treatment of orphans. Male guardian, who is responsible for managing the wealth of the female orphan. However, if the guardian cannot do justice to the woman orphan's property, then a solution is given by possibly marrying the orphan. Muhammad Abduh and Rashid Rida stated that the verse explains the number of wives in the discussion of orphans and the prohibition of consuming their property. If you are worried about eating their property when you marry them, then God allows marriage to other women up to four, but if you cannot be fair, then only one. The condition limits the permission given in the verse on polygamy; that is, if the husband has good morals and economics, he can provide for two or more wives relatively in every condition and avoid abusive behavior split between the two wives. Rida, , Tafsir Kur'âni'l-Hakîm, IV, 339-378.
} 
Muslim must think carefully about adding a wife. Because polygamy takes precedence is justice.

Hamka, however, does not advocate a total ban on polygamy. There are instances when polygamy can be allowed, such as the inability of a wife to bear children. When a wife is barren, he asserts that there is no alternative for the husband but to marry again. He argues that it is the instinct of every man to want children of his own blood. Therefore, it is clear that Hamka does not forbid polygamy when there is a valid reason for it. However, when polygamy is meant to fulfill lust, it becomes entirely forbidden.

Besides, when viewed in the birth of Tafsir al-Azhar and Tafsir al-Manar, there are similarities, namely that both were born from lectures in front of the congregation, which were then compiled in written form. Therefore, this interpretation seems communicative and close to the atmosphere and problems faced by society. Although the setting is different, Tafsir al-Manar was born from an Egyptian society's background in the early 19th century. In contrast, Tafsir al-Azhar was born from the background of Indonesian society in the late 91st and early 20th centuries, when the Dutch colonized Indonesia. Muhammad Abduh's lectures were composed of his student Rashid Rida. Meanwhile, Hamka was presented by his students at his dawn recitation, but Hamka wrote the complete list and sent it to a magazine or newspaper. This is the difference in the pattern of scientific transmission of Muhammad Abduh and Hamka so that their oral products become written products (tafsir).

This explanation raises two critical implications, namely, methodological implications and historical implications. The methodological implication means that the development of thoughts on the interpretation of the Qur'an in Indonesia at least includes the continuity of the past but also changes, develops, and produces something new (original). In development, there may be adopting 
the previous thought or adjustment to the local context. Thus the contemporary interpretation model becomes a necessity. The existence of "tajdid" (renewal) attempts to adapt religious teachings to contemporary life and ideal society, interpreting according to the development of science and the social conditions of society. ${ }^{49}$

Finally, there has been the emergence of books of interpretation of the Qur'an with various interpretations from each generation, with the social conditions they experience, and the characteristics of their interpretation of the Qur'an. ${ }^{50}$ Tafsir al-Manar can be seen as a platform for Muhammad Abduh and Rashid Rida to advocate for new approaches to interpreting the Qur'an within the framework of reformist ideas, particularly in Egypt. Likewise, al-Azhar's interpretation emerged at the beginning of Indonesian independence and Islamic reform ideas into Indonesia.

As an example of ad-Dukhan's interpretation: 16, he interprets it by relating the events that occurred at that time, namely the bombing tragedy in Hiroshima and Nagasaki, Japan, politic, and others. It is also essential that Hamka also displays rhymes and poetry in his interpretation. So it is not surprising that this interpretation is called the tafsir with the "Adab Ijtima' $i$ " approach by the community's conditions. The meaning again is that Tafsir alAzhar is suitable; the interpretation can be applied. The Malayspeaking Southeast Asian community can accept it because it is more touching in the people's minds and hearts and is less suitable to be applied by people who read interpretations from outside the

${ }^{49}$ Necmettin Gokkir, Dialectic Relationship Between the Qur'an and Society in islamic Hermeneutical Traditions, Vol 20, (Journal of Süleyman Demirel Üniversitesi İlahiyat Fakültesi, 2008), 3.

50 Farid Esack, Qur'an Pluralism and Liberation (Oxford: One World, Oxford, 1997), 50. And, J.J. G. Jansen, The Interpretation of The Koran in Modern Egypt (Leiden: E.J.Brill, 1980), 18-19. 
Southeast Asian region. Because of the "feel / zouq" words, sentences, the interpreters use different languages.

Hamka became the forerunner for the development of interpretation in the contemporary period in Indonesia. Contemporary interpretation models using a new approach have started to appear in the early 1990s until now. The interpretation of Al-Azhar is still being used and researched, and then religious ideas in its interpretation are approved by the Indonesian Muslim community.

Then the historical implication is that Hamka's Tafsir also seems to have inspired a small group of Muslim communities who want to return to state rule in Islam. Such as the Jakarta Charter (Piagam Jakarta) now appears in Sharia-based Regional Regulations (Perda $)^{51}$, such as Aceh, several regions in South Sulawesi, Riau, South Kalimantan, etc., which have the most Muslims in that area.

In addition, during this interpretation period, and after Hamka's death, some of them in the form of post-constituent Islamic political parties, both parties or socio-religious groups, have proclaimed themselves as parties or groups with a vision towards an Islamic state or the enactment of an Islamic state. Islamic teachings as the basis of its movement. This is part of the small implications of Hamka's interpretation in his al-Azhar interpretation based on the spirit of renewal of Muhammad Abduh-Rashid Rida in Indonesia.

\section{CONCLUSION}

The development of early modern Islamic thought in the Middle East had a significant influence on Indonesia. In the field of Tafsir, it begins with the Tafsir Al-Manar by Muhammad AbduhRashid Rida. These thoughts and Tafsir's have had a significant

51 Haedar Nashir, Gerakan Islam Syariat: Reproduksi Salafiyah Ideologis di Indonesia (Jakarta: Psap, 2007), 282-385. 
influence on interpretation in Indonesia, especially Tafsir Al-Azhar. The author of this Tafsir lived during the Dutch colonial era and the Indonesian independence era. His thoughts appeared on Indonesia's condition experiencing transition, both in socio-culture, education, and thoughts of Indonesian Muslims. This Tafsir is written to explain the Indonesian Islamic community diverse from culture and religion. Hamka himself admits this in his Tafsir. Besides, Tafsir Al-Azhar's model, style, and methodology are similar to Tafsir al-Manar, especially in explaining al-Qur'an verses' interpretation in a comfortable, understandable way, and straightforward manner the tafsir reader. Of the nine volumes of Al-Azhar's exegesis, the writer found approximately 68 quotes from Tafsir al-Manar. Sometimes describing al-Manar's interpretation as it is, and sometimes summarizing it, taking the essence of Muhammad Abduh-Rida's interpretation. For example, the problem of Israiliyat, muhkammutasyabih, and others.

Besides, when viewed in the birth of Tafsir Al-Azhar and Tafsir Al-Manar, there are similarities, namely that both were born from lectures in front of the congregation, which were then compiled in written form. Therefore, this interpretation seems communicative and close to the atmosphere and problems faced by society. Although the setting is different, Tafsir al-Manar was born from Egyptian society's early 19th-century background. In comparison, Tafsir al-Azhar was born from Indonesian society's background in the late 19th and early 20th centuries, when the Dutch colonized Indonesia. Muhammad Abduh's lectures were composed by his student Rashid Rida. Meanwhile, Hamka was presented by his students at his dawn recitation, but Hamka wrote the complete list and sent it to a magazine or newspaper.

Hamka's enthusiasm in writing Tafsir Al-Azhar greatly influenced the emergence of subsequent interpretations. This means 
that the interpretation can be applied and accepted by the people of Southeast Asia who speak Malay because it is more touching in the minds and hearts of the people and is less suitable for application by people who read interpretations outside the Southeast Asian region. Due to the "feel / zouq" words, sentences, the interpreters use different languages.

\section{REFERENCES}

Abduh, Muhammad. Juz 'Amma. Cairo: Syirkah Musahamah Misriyyah, 1341/1922.

al-'Adawi, Ibrahim Ahmad. Rashid Rida al-Imam al-Mujahid. Cairo: Muassasa Misriya Amma, nd.

Al-Farmawi, Abd al-Hayy. Al-Bidayah fi Al-Tafsir Al-Maudhu'i. Kairo: Al-Hadarah Al-'Arabiyah. nd

Al-Qathan, Manna'. Mabahis fi 'Ulum Al-Qur'an. Cairo: Maktabah Wahbah, 2000.

al-Sabbâgh, Muhammad b. Lutfî. Lamahât fi-'Ulûm Kur'ân. Beyrüt: Maktabah al-Islâmî, 1990.

Esack, Farid. Qur'an Pluralism and Liberation. Oxford: One World, 1997.

Az-Zahabi, Muhammad Husein. Al-Tafsir wa Al-Mufassirun. Cairo: Maktabah Wahbah, 2005.

Muhammad Husein. Israiliyat fi-Tafsir ve Hadis. Kahire: Majalat al-Azhar, 1968.

Fadzilah Din, "The Contribution of Tafsir AL-Manar and Tafsir AlAzhar Toward Understanding The Concept of Ta'ah And Its Observance: A Theological Enquiry." Doktoral Thesis, UK, University of Edinburgh, 2001.

Federspiel, Howard M. Deepening Faith and Strengthening Behaviour: Indonesian Studies of Qur'an and Hadith. Jakarta: Privately Published, 1987. 
......., Howard M, Kajian-kajian Al-Qur'an di Indonesia. Bandung: Mizan, 1996.

Fog, Kevin W., "Hamka's Doctoral Adress, at Al-Azhar; The Influence of Muhammad Abduh in Indonesia", Indonesian Interdisciplinary Journal of Islamic Studies, 11, 2, (2015).

Gokkir, Necmettin. Dialectic Relationship Between the Qur'an and Society in islamic Hermeneutical Traditions. Vol 20, Journal of Süleyman Demirel Üniversitesi İlahiyat Fakültesi, 2008.

Goldziher, Ignaz. Mazahib al-Tafsir. trans. Abdul Halim. Cairo: Maktabah el-Hanaci, 1995.

Nashir, Haedar. Gerakan Islam Syariat: Reproduksi Salafiyah Ideologis di Indonesia. Jakarta: Psap, 2007.

Hamka. Kenang-Kenangan Hidup. Jakarta: Bulan Bintang, 1974. Tafsir al-Azhar, 1. Jakarta: Gema Insani, 2015.

............, Pengaruh Muhammad 'Abduh di Indonesia, Jakarta: Tintamas, 1961

Hamka, Rusydi. Pribadi dan Martabat. Jakarta: Pustaka Panji Mas, 1981.

Imani, Ayatullah Sayyid Kamal Faghih. Nur al-Qur'an: An Enlightening Commentary Into The Ligh Of The Holy Qur'an. Iran: Imam Ali Public Library, 1998.

İmârah, Muhammed, el-Emâl Kemile, I. Cairo: Der al-Surûk, 2009.

Jansen, J.J. G. The Interpretation of The Koran in Modern Egypt. Leiden: E.J.Brill, 1980.

Nata, Abuddin, Metodologi Studi Islam. Jakarta: Raja Grafindo, 2000.

Razikin, Badiatul. 101 Jejak Tokoh Islam. Yogyakarta: e-Nusantara, 2009.

Rida, Rashid, Tafsir al-Kur'an al-Hakim, IV, Cairo: Dar El-Menar, 1947. 
Saeed, Abdullah, Ed. Approaches to the Qur'an in Contemporary Indonesa. London: Oxford Univeristy Press, 2005.

....., Abdullah. The Qur'an: An Introduction. New York: Routledge, 2008.

Salam, Solihin. Kenang-kenangan 70 Tahun Buya Hamka. Jakarta: Yayasan Nurul Islam, 1978.

Salih, Abdülkadir Muhammaed. et-Tefsîrû ve'l-Mufessirûn fíl-'Asri'lHadîs, Beirut: Der Marife, 2003.

Syafi'i, Abdul Manan, "Pengaruh Tafsir al-Manar terhadap Tafsir AlAzhar", Miqot Journal, 38, 2, (2014).

Yunus, Muhammad. Sejarah Pendidikan Islam di Indonesia. Jakarta: Hida Karya Agung, 1996.

Yusuf, Milhan. “Hamka's Method Of Interpretıng The Legal Ayats Of The Qur'an: A Study Of His Tafsiral-Azhar." Master Thesis, Canada: McGill University, 1995.

Yusuf, Yunan. Corak Pemikiran Kalam Tafsir Al-Azhar: Sebuah Telaah Atas Pemikiran Hamka dalam Teologi Islam. II, Jakarta: Penerbit Penamadai, 2003. 
Zulfikri Zulkarnaini \& Mohammed A.F. Badawi

148 | Millah Vol. 21, No. 1 Agustus 2021 